\title{
FLOOD PATTERN CHANGES IN THE RIVERS OF THE BALTIC COUNTRIES
}

\author{
Diana SARAUSKIENE ${ }^{\mathrm{a}}$, Jurate KRIAUCIUNIENE ${ }^{\mathrm{a}}$, Alvina REIHAN ${ }^{\mathrm{b}}$, Maris KLAVINS ${ }^{\mathrm{c}}$ \\ ${ }^{a}$ Laboratory of Hydrology, Lithuanian Energy Institute, Breslaujos g. 3, 44403 Kaunas, Lithuania \\ ${ }^{b}$ Institute of Environmental Engineering, Tallinn University of Technology, Ehitajate tee 5, 19086 Tallinn, Estonia \\ ${ }^{c}$ Faculty of Geography and Earth Sciences, University of Latvia, Raina Blvd. 19, 1586, Riga, Latvia
}

Submitted 16 Apr. 2013; accepted 18 Jun. 2014

\begin{abstract}
Estimation of both the frequency and variation of spring floods is a key issue for the assessment and management of flood risks. Changes in river floods in Estonia, Latvia and Lithuania have been investigated in few national studies. However, there are no studies of the changes of flood patterns by using a common methodology for the rivers of this region. In this study flood pattern changes in the rivers of the Baltic countries were estimated applying trend and frequency analysis for the periods of 1922-2010, 1922-1960, 1961-2010 and 1991-2010, i.e. for the whole spring flood data sets, periods before and after 1960 (this year was considered as the beginning of the remarkable climate change), as well as for the two past decades. A comparative study of five probability distributions was performed in order to estimate which distribution at best represents statistical characteristics of the flood data. The results showed that maximum discharges of spring floods decreased over the whole studied period. Only some insignificant positive trends of maximum discharges were found in the last time period in continental and transitional rivers. Generalized extreme value distribution provided the best approximation to the maximum discharge data series of the rivers of Baltic countries for the whole observation period.
\end{abstract}

Keywords: Baltic countries, rivers, environmental monitoring, maximum discharge, spring floods, trends, probability distributions.

\section{Introduction}

Flooding is the most pervasive natural hazard. According to EU Directive 2007/60/EC on the assessment and management of flood risks, floods have the potential to cause fatalities, displacement of people and damage to the environment, to severely compromise economic development and to undermine the economic activities of the Community. It is feasible and desirable to reduce the risk of adverse consequences, especially for human health and life, the environment, cultural heritage, economic activity and infrastructure associated with floods.

Recently, significant attention is paid to analysis of this very special hydrological regime phase. Since the 1990s extensive and repeated floods across Europe have been bringing a lot of damage and loss (Arduino et al. 2005; Barredo 2009; De Wrachien et al. 2011). That shows failure of contemporary flood prevention approaches to control natural processes, despite the significant funding that is spent for flood prevention measures.
For evaluation of the risk of flooding it is important to predict the time of its occurrence and magnitude of floods heights and also it is necessary to ensure the reliability of various hydro technical structures. This analysis should neither underestimate nor overestimate magnitude of such an event. At the same time climate change is expected to increase flood frequency and its magnitude through increased precipitation. Several studies showed that seasonality of changes varies with location: increases are strongest in the warm season in the USA; while in Europe changes are most notable in the cool season (Groisman et al. 2004; Haylock, Goodess 2004; Villarini et al. 2011). Research in the Baltic countries showed that maximum discharge of spring floods tends to decrease in the most regions (Apsite et al. 2011; Kriauciuniene et al. 2012; Latkovska et al. 2012; Reihan et al. 2012), however, there some questions may arise in the context of climate change: if trends observed in flood series continue in the future or if the historical data are quite good to represent the future flood events?

Corresponding author: Diana Sarauskiene

E-mail: eko@mail.lei.lt 
Many studies showed not clear increase of magnitude of flood events but what is promised that flood events can be more frequent. In the Northern Europe, Dankers and Feyen (2008) reported a considerable reduction of 10-40\% in 100-year discharges in Finland, much decreases in northern Sweden and north-western Russia by the end of the century due to decrease in snow accumulation; however Lehner et al. (2006) evaluated that the 100-year floods in the same areas will occur more frequently by the 2070 s.

To protect inundated areas and provide floods risk assessment the flood frequency analysis (FFA) is used as the most well-known procedure to ensure the reliable estimation of expected floods and their frequency. Main spring flood parameters, such as maximum discharge, flow duration, are usually used in FFA analysis. These parameters have already been investigated in the Baltic States (Gailiusis et al. 2001; Dumbrauskas et al. 2008; Klavins et al. 2009, etc.). The annual peak series with more than 50 observations for 40 streams in Estonia, Latvia and Lithuania were studied previously, however, there is no common procedure for the FFA in all these three countries and therefore the results of the same analysis can differ from one another. In Lithuania and in Latvia usually normal and Gumbel distribution laws were used to calculate the parameters, but Estonian hydrologists preferred logPearson type III distribution. Therefore, choice of the distribution most suitable to the recorded sample series is important from these aspects.

Gailiusis et al. (2001) calculated parameters of probability curve for the most of Lithuanian rivers. Recently, Sarauskiene and Kriauciuniene (2011) examined different probability distributions for spring flood frequency analysis in Lithuania for different periods with a focus on probability distribution fitting to the actual data in spring flood time. Their studies showed that the log-Pearson type III and generalized extreme value distributions are the most suitable for the Lithuanian rivers. However, such analysis is not performed yet in Estonia and Latvia.

The aim of this study is to analyse and to compare the patterns of spring flood data in the selected rivers from different hydrological regions in the Baltic countries applying trend analysis, calculating anomalies and estimating the best fit of probability distribution for the selected periods.

\section{Data}

The Baltic countries are north-eastern region of Europe containing the countries of Estonia, Latvia, and Lithuania, on the eastern shores of the Baltic Sea. These countries cover relatively small area, although hydro-meteorological differences across the States are significant. The territory of the Baltic States is divided into nine hydrological regions (3 regions in each country) (Fig. 1a) (according to Reihan et al. 2012). The regions of western Lithuania (W-LT), Latvia (W-LV) and Estonia (W-ES), the territory which is close to the Baltic Sea, belong to the marine climate zone and the main source of river feeding is precipitation. South-eastern Latvia (SE-LV) and Lithuania (SE-LT) together with eastern Estonia (E-ES) are the continental part of the Baltic States. The rivers of this

a)
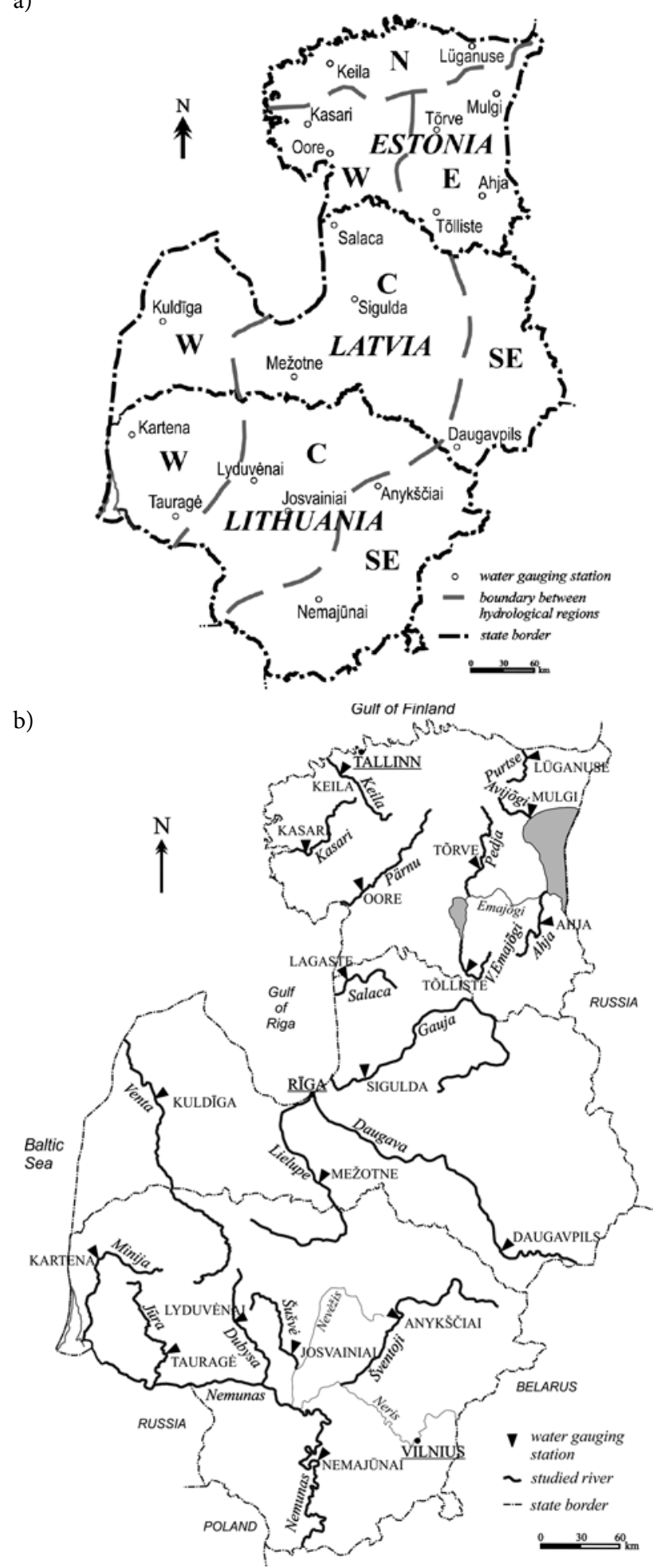

Fig. 1. Hydrological regions, 19 water gauging stations (a) and studied rivers across the Baltic States (b) 
territory have prevailing snowmelt and subsurface feeding and the annual discharge of these rivers is distributed rather equally. The patterns of the other hydrological regions (N-ES, C-LV and C-LT) of the Baltic States are of a more individual character (Fig. 1a), the authors called these rivers transitional.

Annual maximum discharge data for the present study were obtained from Estonian Meteorological and Hydrological Institute, Latvian Environmental, Geology and Hydrometeorological Centre and Lithuanian Hydrometeorological Service. Annual maximum discharge time series at 19 water gauging stations across the Baltic States were used (Table 1, Fig. 1b). The rivers were selected according to availability and quality of data, i.e. there were used long data series and the rivers that are unaffected by significant upstream regulation. Average duration of observations was 83 years. The catchments of selected rivers at water gauging stations (WGS) have a different size (Table 2). The rivers were chosen so as to characterize the regime of the hydrological regions to which they belong.

Table 1 . Summary of the used data

\begin{tabular}{lcc}
\hline \multicolumn{1}{c}{ Country } & Number of WGSs & $\begin{array}{c}\text { Station-years } \\
\text { of data }\end{array}$ \\
\hline Estonia & 8 & 632 \\
Latvia & 5 & 478 \\
Lithuania & 6 & 470 \\
The Baltic States & 19 & 1580 \\
\hline
\end{tabular}

In order to evaluate flood frequency changes over time and to investigate climate change impact on spring flood events the analysis was made for different periods: 1922-2010, 1922-1960, 1961-2010 and 1991-2010.

\section{Methods}

The calculation of trend statistics of spring flood data series was based on the nonparametric Mann-Kendall test (Gilbert 1987). This procedure (Mann-Kendall test) is used since missing values are allowed and the data do not need to conform any particular distribution. In this study the significance of trend was tested by using three different $\alpha$ levels of significance: $\alpha=0.05, \alpha=0.01$ and $\alpha=0.001$.

There are many probability distributions that are selected for flood projections in different countries all over the world. However, there is no one specific universal distribution for modelling flood data. In addition, some later conclusions from the various analyses of outputs for both real and modelled data showed that by employing several alternative distributions to the time series for a catchment one can hardly get the same distribution for samples for another duration (Mitosek et al. 2006; Kidson, Richards 2005).

In this study five widely used probability distributions were suggested and compared. Gumbel (EV1), generalized extreme value (GEV), log-Pearson type III (LP3), three-parameter lognormal (LN3) and generalized logistic (GLO) (Table 3) were selected for the analysis of statistical characteristics of observed flood data of the rivers in the Baltic States.

Table 2. Description of the river data

\begin{tabular}{|c|c|c|c|c|c|c|}
\hline River & WGS & $\begin{array}{c}\text { Hydrological } \\
\text { region }\end{array}$ & $\begin{array}{c}\text { Catchment area, } \\
\mathrm{km}^{2}\end{array}$ & $\begin{array}{l}\text { Record period } \\
\text { (years) }\end{array}$ & $\begin{array}{c}\text { Mean discharge } \\
\left(\mathrm{m}^{3} / \mathrm{s}\right)\end{array}$ & $\begin{array}{c}\text { Annual maximum } \\
\text { discharge }\left(\mathrm{m}^{3} / \mathrm{s}\right)\end{array}$ \\
\hline \multicolumn{7}{|c|}{ Continental type rivers } \\
\hline Ahja & Ahja & E-ES & 909 & 1960-2010 & 29.49 & 111 \\
\hline Avijogi & Mulgi & E-ES & 366 & 1955-2010 & 25.41 & 55.7 \\
\hline V. Emajõgi & Tõlliste & E-ES & 1050 & $1922-2010$ & 63.62 & 198 \\
\hline Pedja & Tõrve & E-ES & 776 & 1925-2010 & 52.04 & 200 \\
\hline Daugava & Daugavpils & SE-LV & 64500 & $1922-2010$ & 2552 & 6930 \\
\hline Šventoji & Anykščiai & SE-LT & 3600 & $1928-2010$ & 143.42 & 423 \\
\hline Nemunas & Nemajūnai & SE-LT & 42800 & $1922-2010$ & 919.15 & 3460 \\
\hline \multicolumn{7}{|c|}{ Marine type rivers } \\
\hline Venta & Kuldīga & W-LV & 8320 & $1922-2010$ & 589.44 & 1300 \\
\hline Minija & Kartena & W-LT & 1230 & $1925-2010$ & 118.73 & 287 \\
\hline Jūra & Tauragė & W-LT & 1690 & 1926-2010 & 206.78 & 510 \\
\hline Kasari & Kasari & W-ES & 2640 & $1925-2010$ & 206.06 & 703 \\
\hline Pärnu & Oore & W-ES & 5150 & $1922-2010$ & 319.74 & 810 \\
\hline \multicolumn{7}{|c|}{ Transitional type rivers } \\
\hline Keila & Keila & N-ES & 635 & $1923-2010$ & 39.18 & 144 \\
\hline Purtse & Lüganuse & N-ES & 784 & $1923-2010$ & 53.77 & 156 \\
\hline Lielupe & Mežotne & C-LV & 9390 & $1922-2010$ & 647.23 & 2430 \\
\hline Gauja & Sigulda & C-LV & 8510 & $1940-2010$ & 335.30 & 870 \\
\hline Salaca & Lagaste & C-LV & 3220 & $1926-2010$ & 173.26 & 457 \\
\hline Dubysa & Lyduvènai & C-LT & 1070 & 1933-2010 & 66.35 & 184 \\
\hline Šušvė & Josvainiai & C-LT & 1100 & $1940-2010$ & 80.86 & 312 \\
\hline
\end{tabular}


Generalized extreme value and Gumbel distributions are extreme value distributions widely used for modelling of extreme or rare events such as extreme floods and snowfalls, high wind speeds, extreme temperatures. The Gumbel (EV1) distribution, also known as the extreme value type I distribution, is unbounded (defined on the entire real axis). The generalized extreme value (GEV) distribution is a flexible three-parameter model that combines the Gumbel, Fréchet and Weibull maximum extreme value distributions.

The log-Pearson type III (LP3) is mostly used for annual maximum floods. In the USA, it is a standard distribution for flood frequency analysis.

The generalized logistic (GLO) distribution is also found to perform pretty well for modelling floods in some countries.

The three-parameter lognormal (LN3) distribution is popular in the studies of the frequency analysis of floods as well.

Parameter estimation for the different probability distributions was performed using methods of L-moments (for EV1, GEV, GLO), moments (for LP3) and maximum likelihood (for LN3). Selection of the corresponding distribution was achieved through goodness-of-fit comparison based on the Anderson-Darling test. Product of MathWave Technologies (EasyFit 5.4 with the built-in distribution viewer StatAssist) was used for probabilistic modelling of flood data of the selected rivers.

\section{Results}

\subsection{Spring flood discharge anomalies}

The main sources of spring floods in the Baltic rivers include accumulation of snow during wintertime, hard winters (indicated by sum of negative temperatures during winter), and intensive rainfalls that usually associated with increase of air temperature during the spring season. As far as the Baltic countries are situated in lowlands with extensive river network, the floods are one of the major sources of natural hazards. The flood impacts are aggravated due to location of major cities of the region either in the lowest reaches of biggest rivers or at rivers. Historically several major floods with high damages caused were recorded. Flood threat since 18 th century initiated building of hydrotechnical structures to reduce flood risks and, especially, in the last century number of events of major floods has reduced (Table 4); however as factors affecting flood recurrence also climate change and increase of urban areas can be mentioned. Previous studies (Jaagus 2006; Kriauciuniene et al. 2012) indicate positive air temperature anomalies throughout a year and higher precipitation amounts in the winter season in the recent

Table 3. Probability density functions of the used distributions

\begin{tabular}{|c|c|c|}
\hline Distribution type & Probability density function & Parameters \\
\hline EV1 & $f(x)=\frac{1}{\sigma} \exp (-z-\exp (-z))$ & $\begin{array}{l}\sigma-\text { continuous scale parameter }(\sigma>0) ; \\
\mu-\text { continuous location parameter; } \\
z \equiv \frac{x-\mu}{\sigma}\end{array}$ \\
\hline GEV & $f(x)=\left\{\begin{array}{cc}\frac{1}{\sigma} \exp \left(-(1+k z)^{-\frac{1}{k}}(1+k z)^{-1-\frac{1}{k}}\right. & k \neq 0 \\
\frac{1}{\sigma} \exp (-z-\exp (z)) & k=0\end{array}\right.$ & $\begin{array}{l}k \text { - continuous shape parameter; } \\
\sigma \text { - continuous scale parameter }(\sigma>0) ; \\
\mu-\text { continuous location parameter; } \\
z \equiv \frac{x-\mu}{\sigma}\end{array}$ \\
\hline LP3 & $f(x)=\frac{1}{x|\beta| \Gamma(\alpha)}\left(\frac{\ln (x)-y}{\beta}\right)^{\alpha-1} \exp \left(-\frac{\ln (x)-y}{\beta}\right)$ & $\begin{array}{l}\alpha-\text { continuous parameter } \\
(\alpha>0) ; \\
\beta-\text { continuous parameter }(\beta \neq 0) \\
\gamma-\text { continuous parameter }\end{array}$ \\
\hline LN3 & $f(x)=\frac{\exp \left(-\frac{1}{2}\left(\frac{\ln (x-y)-\mu}{\sigma}\right)^{2}\right)}{(x-\gamma) \sigma \sqrt{2 \pi}}$ & $\begin{array}{l}\sigma \text { - continuous parameter }(\sigma>0) \\
\mu \text { - continuous parameter; } \\
\gamma \text { - continuous location parameter }\end{array}$ \\
\hline GLO & $f(x)= \begin{cases}\frac{(1+k z)^{-1-1 / k}}{\sigma\left(1+(1+k z)^{-1 / k}\right)^{2}} & k \neq 0 \\
\frac{\exp (-z)}{\sigma(1+\exp (-z))^{2}} & k=0\end{cases}$ & $\begin{array}{l}k \text { - continuous shape parameter; } \\
\sigma \text { - continuous scale parameter }(\sigma>0) ; \\
\mu \text { - continuous location parameter }\end{array}$ \\
\hline
\end{tabular}


decades in the territory of the Baltic countries. Significant changes in land use are also happening: urban areas are growing up; movement of people from rural to urban areas is obvious.

Table 4 shows the numbers of spring floods with probability equal or less than $10 \%$ in the studied rivers. The number of spring floods of the selected probability in the whole studied period comprised from 5 to 9 . The comparison of two periods of the same length, 1922-1960 and 1961-1999, showed significant decrease of the spring floods (of the selected probability); in 7 rivers no cases of such floods were recorded. The exception is two Lithuanian rivers of the marine type, the Minija and the Jura, where the number of the spring floods increased (to $5 \mathrm{ca}$ ses in 1961-1999). In the last two decades a single spring flood or no floods with $\leq 10 \%$ probability occurred. The reason of flood decreasing could be warmer winters, smaller thickness and duration of snow cover in the last year period.

Decrease of spring flood discharges can be observed using other methods of analysis, like estimation of anomalies. Anomalies of annual maximum discharge data were calculated as a ratio, expressed by \%, between the flood discharges of a particular year and the mean maximum spring discharge of the long-term period (Figs 2-4).

Flood discharge anomalies in the continental rivers (Fig. 2) showed that annual maximum discharges have decreased from 1961. In the period of 1922-1960 there were many high positive anomalies (the greatest flood discharges in the studied period: in 1926 - 284\% in the Pedja, in 1931 - 211\% in the V.Emajogi, $172 \%$ in the Daugava and $195 \%$ in the Sventoji, in $1958-276 \%$ in the Nemunas and in $1960-276 \%$ in the Ahja). These great anomalies were caused by exceptionally big floods in the period. From 1961 the amount of positive and negative anomalies was almost the same. In the last two decades the most spring flood maximum discharges were less than the mean value of the long term period.

Flood discharge anomalies in the marine rivers (Fig. 3) indicate more even distribution of maximum flood discharges than in continental rivers. A significant decrease of spring maximum discharges can be noticed from 1971 to 1975 that could be caused by the decreased precipitation amounts from the seventh decade (Reihan et al. 2012). Only in the Minija the biggest flood was observed in 1994 (anomaly of 142\%), whereas in other rivers the greatest positive anomalies calculated till 1970: in 1931 $241 \%$ in the Kasari and $153 \%$ in the Parnu, in $1951-121 \%$ in the Venta, in $1968-147 \%$ in the Jura.

In transitional rivers (Fig. 4), like in marine rivers, much bigger than the average spring flood discharges were observed till 1970; the greatest floods also occurred in this period, whereas very low values of spring floods were recorded in 1971-1977 (possibly also due to the decreased precipitation amounts) and since then negative flood anomalies dominated.

Table 4. Number of big spring floods (probability of $\leq 10 \%$ ) in the rivers of continental (a), marine (b) and transitional type (c)

a)

\begin{tabular}{cccccccc}
\hline Periods & Ahja & Avijogi & V. Emajogi & Pedja & Daugava & Sventoji & Nemunas \\
\hline $1922-2010$ & & & 10 & 9 & 8 & 8 & 11 \\
$1922-1960$ & & & 10 & 9 & 7 & 8 & 9 \\
$1961-1999$ & 3 & 2 & 0 & 0 & 1 & 0 & 0 \\
$1991-2010$ & 1 & 1 & 0 & 0 & 0 & 0 \\
\hline
\end{tabular}

b)

\begin{tabular}{cccccc}
\hline Periods & Kasari & Parnu & Venta & Minija & Jura \\
\hline $1922-2010$ & 8 & 8 & 9 & 9 & 8 \\
$1922-1960$ & 7 & 8 & 8 & 4 & 3 \\
$1961-1999$ & 1 & 0 & 1 & 5 & 5 \\
$1991-2010$ & 0 & 0 & 0 & 1 & 1 \\
\hline
\end{tabular}

c)

\begin{tabular}{|c|c|c|c|c|c|c|c|}
\hline Periods & Keila & Purtse & Lielupe & Gauja & Salaca & Dubysa & Susve \\
\hline $1922-2010$ & 8 & 9 & 9 & 5 & 9 & 9 & 6 \\
\hline $1922-1960$ & 8 & 8 & 9 & 4 & 7 & 5 & 4 \\
\hline 1961-1999 & 0 & 1 & 0 & 0 & 1 & 4 & 2 \\
\hline 1991-2010 & 0 & 0 & 0 & 1 & 1 & 0 & 0 \\
\hline
\end{tabular}




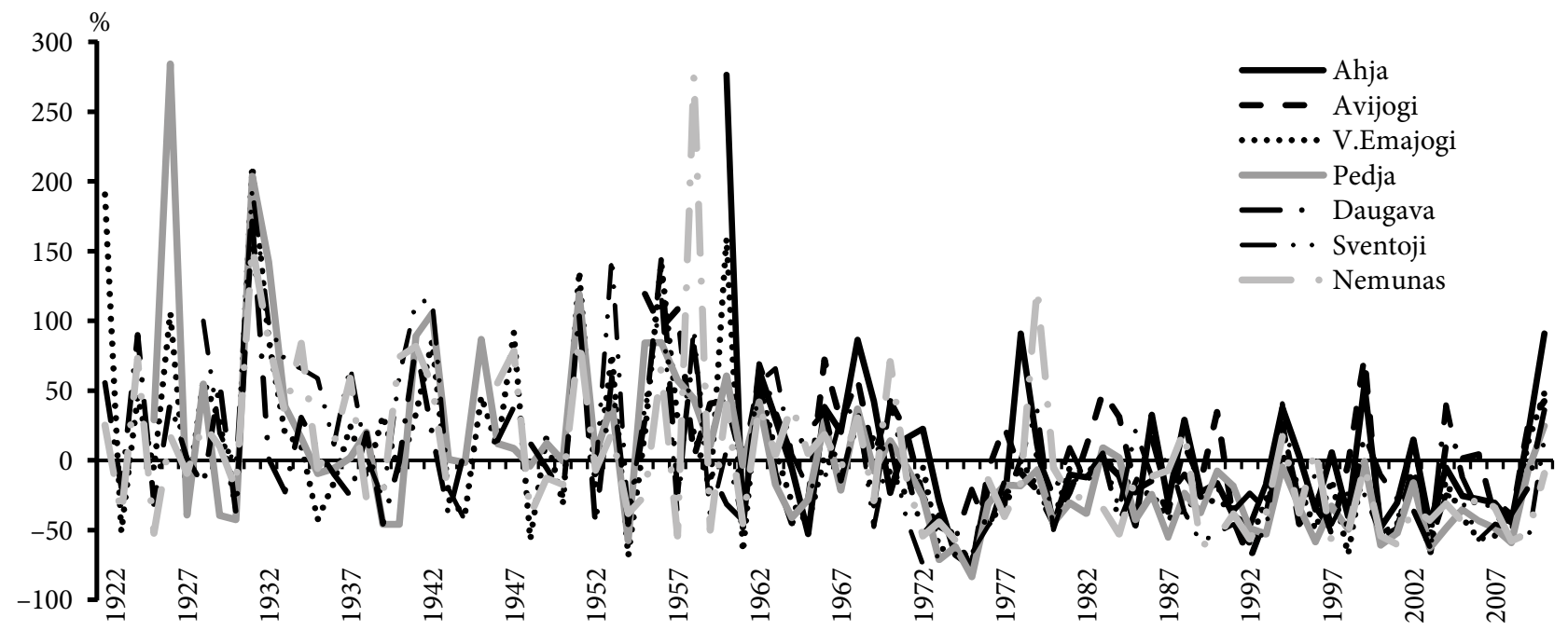

Fig. 2. Annual maximum spring flood anomalies (\%) from the long-term average in the continental rivers

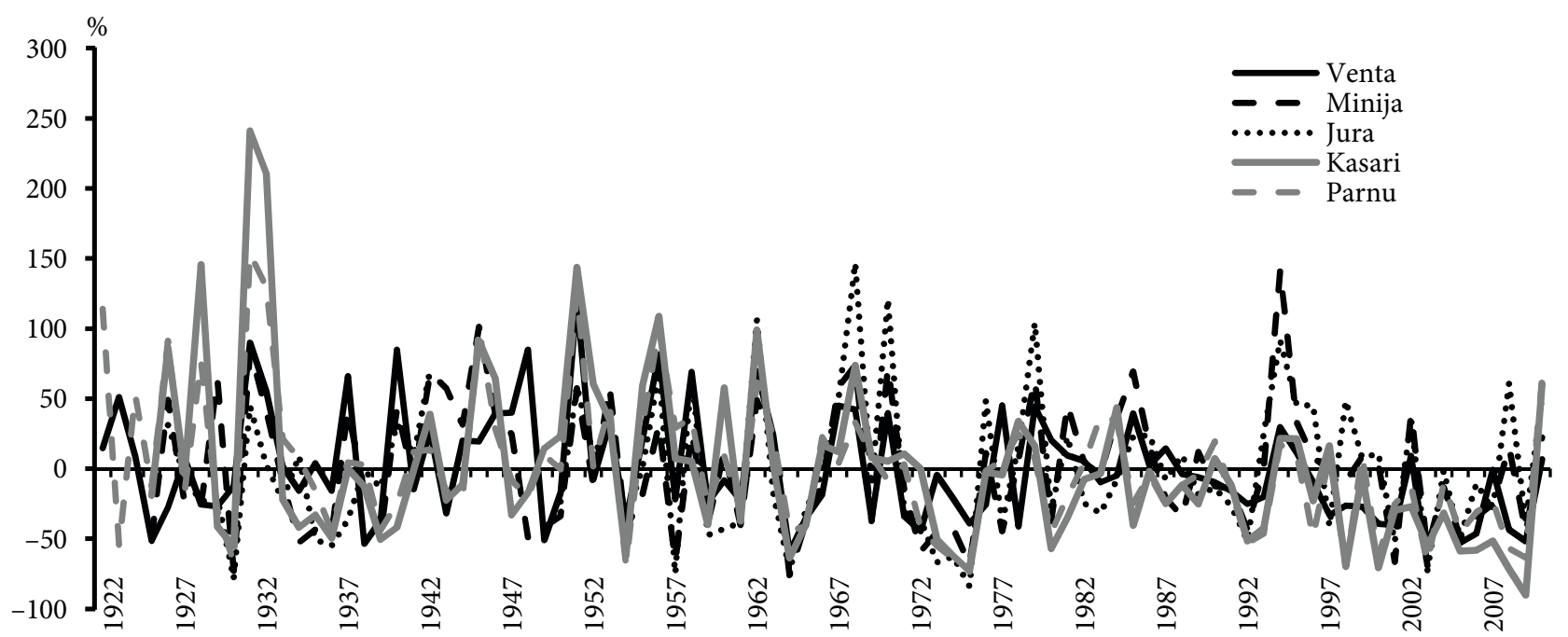

Fig. 3. Annual maximum spring flood anomalies (\%) from the long-term average in the marine rivers

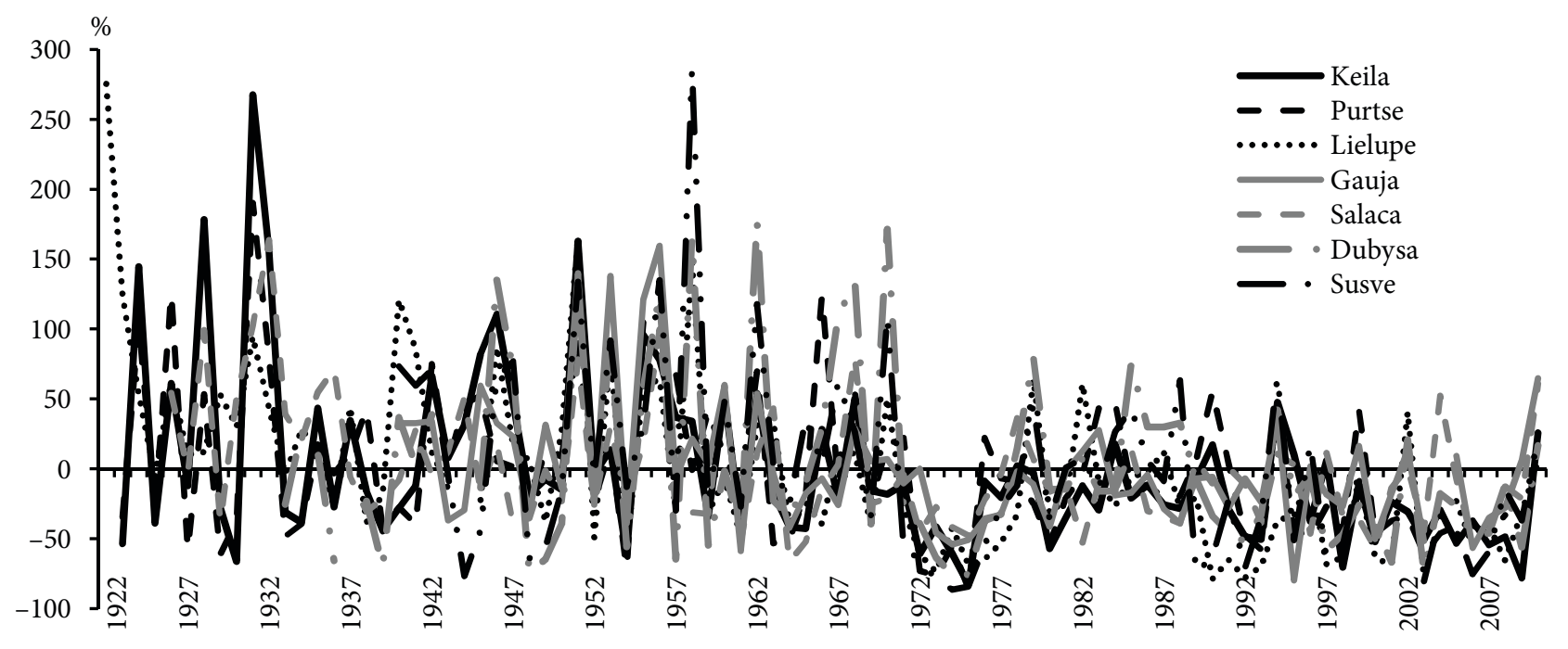

Fig. 4. Annual maximum spring flood anomalies (\%) from the long-term average in the transitional rivers 


\subsection{Trend analysis}

Trend analysis was performed for the whole spring flood data sets (1922-2010), periods before and after 1960, i.e. the beginning of the remarkable climate change (BACC Author Team 2008): 1922-1960 and 1961-2010, as well as for the two past decades (1991-2010). The trend was considered as statistically significant at the $5 \%$ level if the test statistics was greater than 1.65 or less than -1.65 .

In the longest analysed period (1922-2010) the studied flood discharge time series had negative trends, except in the Jura and the Minija, both marine type rivers and both with the smallest catchment area in this group. Their trends can differ from other results since in small watersheds influence of local factors on the value of spring flood is more significant than other factors such as climate change for example. The Dubysa (transitional type river), where only poor insignificant trend was detected, was also the exception from the general decreasing tendencies (Fig. 5). Four (out of five rivers that have measurements for this period) continental rivers showed trend at $\alpha=$ 0.001 level, i.e. the detected trends were very significant. Trends of the same significance were found in two transitional rivers: the Keila and the Lielupe as well. The reason of such character of floods may be the fact that in all continental rivers the highest (or the second highest) floods occurred in 1931, i.e. in the beginning of the studied period, and later in most cases maximum flood discharges were getting less and less. In spring of 1931 Estonia suffered damaging floods, $2 \%$ of its land was under water (RPV USSR 1972). Table 4 (b) and Figure 3 can explain why the data of two marine rivers in Lithuania, the Minija and the Jura, do not have clear trend: they both had high spring floods (of probability $\leq 10 \%$ ) before and after 1961, moreover, the most spring flood discharge peaks were measured in the last four decades of 20th century.

The analysed above long-term period was split into two separate time slices: 1922-1960 and 1961-2010. Analysis showed (Fig. 5) no significant trend (neither negative nor positive) in maximum flood discharges in 1922-1960, except for two transitional rivers: the Lielupe and the Salaca in Latvia, where Mann-Kendall test displayed significant negative trends at $\alpha=0.05$ level. And since there is no trend in other rivers it can be concluded that in the studied river basins flood regime (as well as natural and anthropogenic factors that influence it) was relatively stable in this time period.

Starting from 1961 (Fig. 5) the decreasing tendencies of flood discharges in the most of rivers were detected, however only in the continental type rivers: the Pedja, the Daugava and the Nemunas, and marine rivers: the Kasari, the Parnu and the Venta, changes were more pronounced and can be defined as significant.

In the last 20-year period only two marine type rivers: the Kasari and the Venta had significant negative trends at $\alpha=0.05$ level in the flood data sets (Fig. 5). Also it should be mentioned that some opposite (positive) insignificant trends were observed in the selected rivers of continental type, whereas for the studied group of transitional rivers no tendencies could be noticed. The recent study of temperature and precipitation changes in the Baltic States (Kriauciuniene et al. 2012) showed that in the last two decades in the eastern regions, i.e. continental part, amount of precipitation in winter increased the most. This precipitation increase together with higher temperatures in the whole region in this period could give such consequences - higher floods in the rivers of continental type, since more rainfall or snowmelt water reached the rivers.

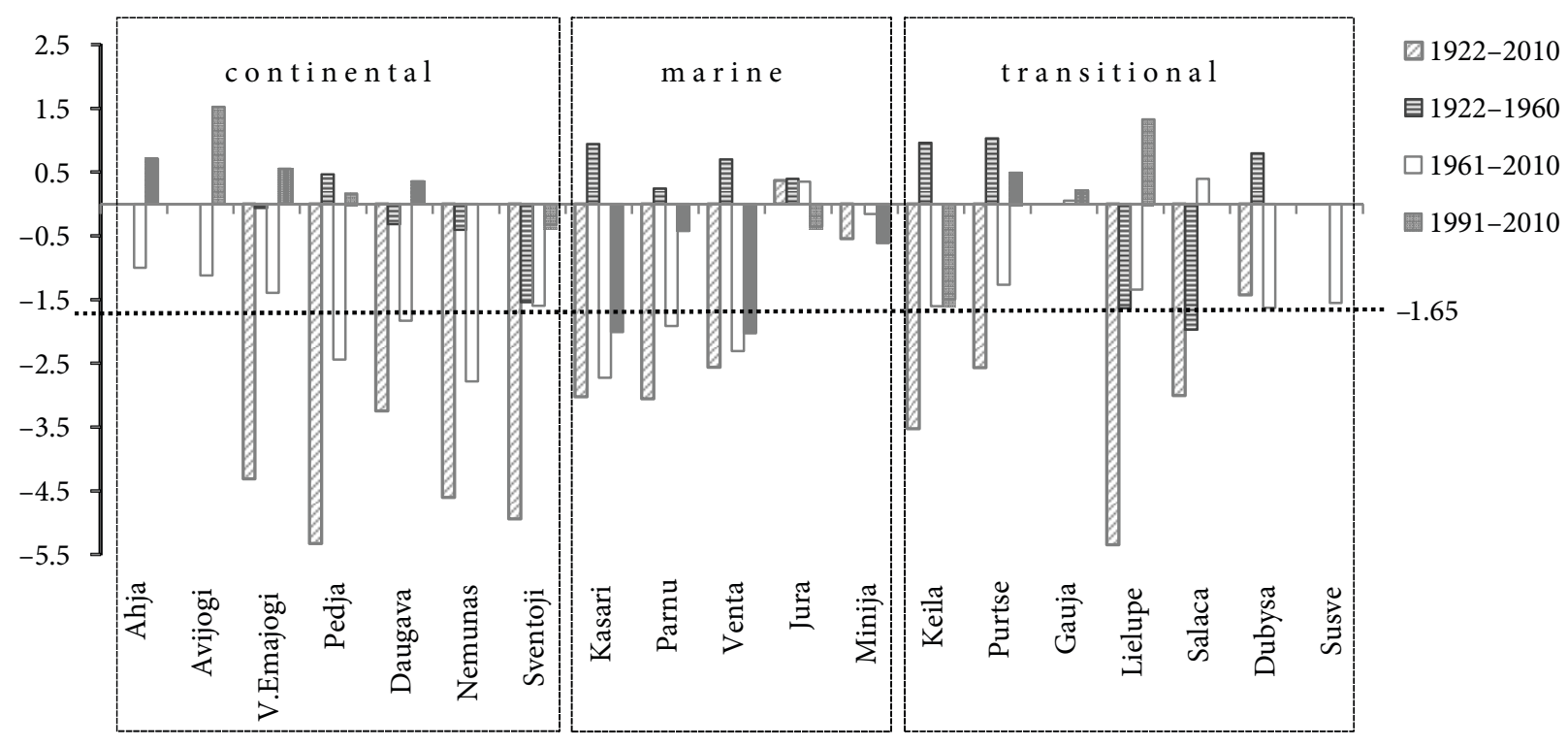

Fig. 5. Trends (according to trend statistics) of annual maximum discharges of spring floods in rivers of different type (continental, marine and transitional) in 1922-2010, 1922-1960, 1961-2010 and 1991-2010 


\subsection{Flood frequency analysis}

In order to assess the spring flood risk, the probability of this event has to be identified.

Annual maximum discharge (spring flood) data of the selected rivers have been fitted to 5 probability distribution (PD) models. The aim of the goodness of fit test is to measure the "distance" between the data and the tested distribution, and compare that distance to some threshold value. If the distance (the test statistic) is less than the threshold value (the critical value), the fit is considered good. The critical values depend on the sample size and the significance level chosen $(\alpha=0.05)$. The distribution with the lowest statistic value is considered as the best fitting model.

The PDs were ranked according to the results of Anderson-Darling (AD) test in order to find out the dominant PD for all studied rivers. The best fitting PD (i.e. the distribution with the lowest statistic value) received rank 1, whereas the worst got rank 6 .

The PD fitting was accomplished for the same observation periods as the trend analysis (1922-2010, 19222060, 1961-2010 and 1991-2010).

The fitting of annual maxima series of different hydrological regions showed that flood distribution approximations differed slightly (Table 5).

In the longest studied period (1922-2010) GEV distribution provided the best approximation to spring flood data in marine rivers, whereas in other studied rivers maximum discharges were mostly GEV or LP3 distributed. In Figure 6 visualisation of the probability distribution fitting

Table 5. Summed fitting ranks according to different distribution functions

\begin{tabular}{lccccc}
\hline \multirow{2}{*}{$\begin{array}{c}\text { River type } \\
\text { (number of used } \\
\text { data series) }\end{array}$} & \multicolumn{5}{c}{ Probability distribution } \\
\cline { 2 - 6 } & GLO & GEV & LP3 & LN3 & EV1 \\
\cline { 2 - 6 } Continental (7) & 22 & 14 & 15 & 19 & 35 \\
Marine (5) & 17 & 9 & 14 & 14 & 21 \\
Transitional (7) & 25 & 15 & 14 & 19 & 32 \\
\hline & & \multicolumn{5}{c}{$1922-1960$} \\
\hline Continental (4) & 15 & 8 & 7 & 13 & 17 \\
Marine (5) & 19 & 10 & 10 & 13 & 23 \\
Transitional (6) & 26 & 11 & 8 & 21 & 24 \\
\hline & \multicolumn{5}{c}{$1961-2010$} \\
\hline Continental (7) & 29 & 10 & 17 & 18 & 31 \\
Marine (5) & 21 & 8 & 9 & 13 & 24 \\
Transitional (7) & 22 & 11 & 22 & 21 & 29 \\
\hline & & \multicolumn{5}{c}{$1991-2010$} \\
\hline Continental (7) & 26 & 13 & 17 & 16 & 33 \\
Marine (5) & 19 & 6 & 13 & 17 & 20 \\
Transitional (7) & 21 & 14 & 18 & 20 & 32 \\
\hline
\end{tabular}

a)
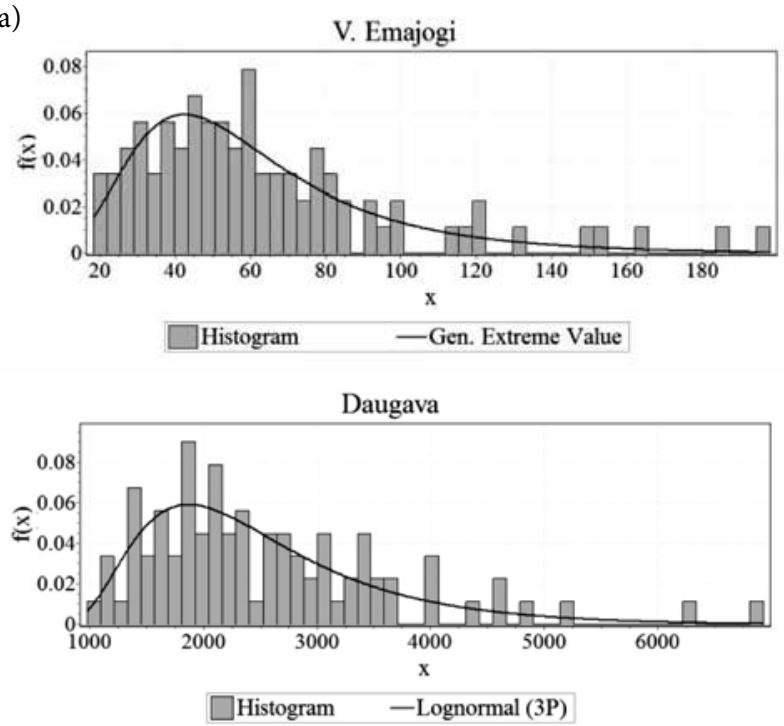

b)
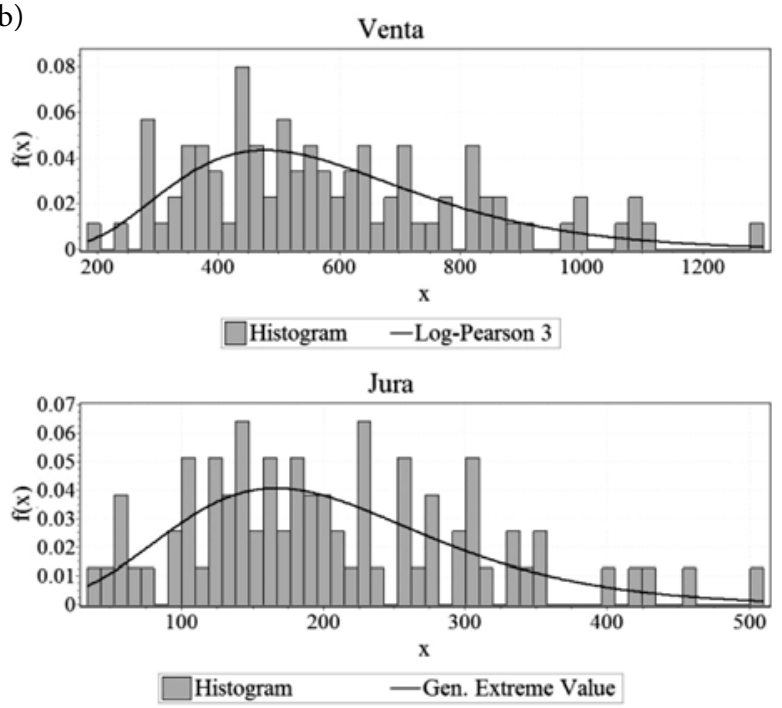

c)

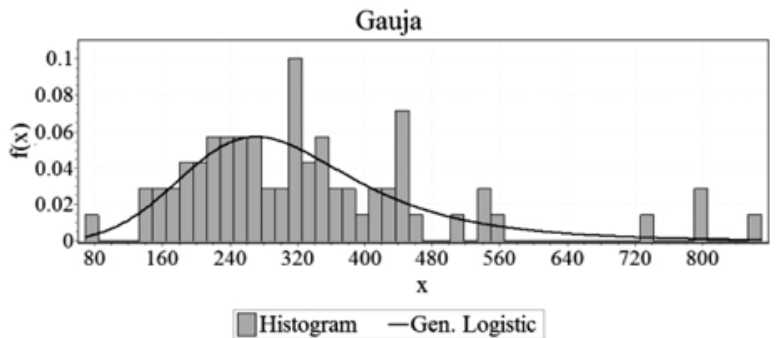

Salaca

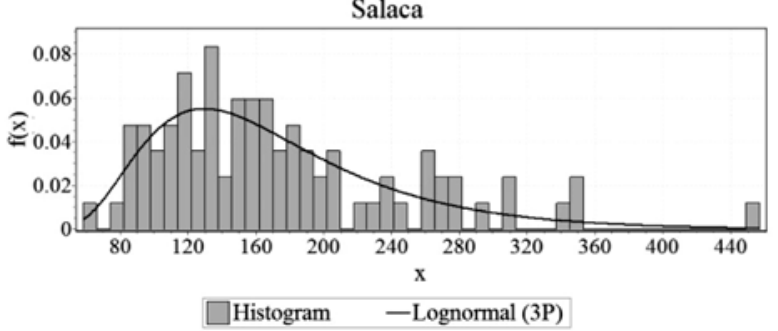

Fig. 6. Results of theoretical probability density function (PDF; displayed as a continuous curve) fitting to the empirical PDF (displayed as a histogram) for: a) continental rivers; b) marine rivers; and c) transitional rivers (in $\mathrm{x}$ axis - annual maximum discharge, $\mathrm{m}^{3} / \mathrm{s}$, in y axis - probability density function) 
to the actual spring flood data of the whole observation period is presented; it shows the probability density functions of the distributions which best fit to the spring flood data (the cases, where $\mathrm{AD}$ test statistics value was the lowest, i.e. less than 0.2).

In the period of 1922-1960 GEV and LP3 models showed the best (almost the same) correspondence to the flood data time series. The data sets after 1960 seemed to be the most similar to GEV distribution patterns; the used goodness of fit test gave very high ranks for this PD when fitting continental and transitional rivers data.

Maximum discharges were definitely GEV distributed in marine, continental and transitional zone of the studied territory in the last two decades as well.

Performed analysis showed that GEV distribution provides the best approximation to spring flood data in all the Baltic countries for all observation periods; LP3 and LN3 were the next best fitted PD; other models, GLO and EV1, were shown to perform poorly (Table 6). Therefore GEV distribution can be employed to estimate the occurrence probability of a given flood event in the studied rivers. This may help a lot in accurate and safe design of bridges, embankments, dams and other hydro technical structures.

Table 6. Final results of goodness of fit test (ranking of probability distributions)

\begin{tabular}{lccccc}
\hline & GEV & LP3 & LN3 & GLO & EV1 \\
\hline Overall summing & 129 & 165 & 204 & 262 & 321 \\
Final rank & I & II & III & IV & V \\
\hline
\end{tabular}

\section{Discussion}

For the analysis of flood pattern changes a group of rivers was selected from each the Baltic State. Each river group consisted of rivers representing three hydrological regions: marine, continental and transitional. The aim was to find out if there were any significant differences concerning spring flood patterns among the rivers of the separate groups in different time periods.

During the whole studied time period in the most of investigated rivers decrease of annual maximum spring flood discharges was observed. The greatest spring discharges were more frequent in the period of 1922-1960. The comparison of the periods of 1922-1960 and 19611999 showed significant decrease of spring floods; only in two Lithuanian rivers of the marine type, the Minija and the Jura, number of the spring floods increased. In the last two decades a single spring flood or no floods of $\leq 10 \%$ probability occurred.

Calculated flood discharge anomalies revealed a clear decrease of floods exceeding mean values since 1961 as well. Beginning from 1961 the amount of positive and negative anomalies was almost the same. The period of 1963-1977 was the driest period of the rivers runoff for all regions of the Baltic countries; that might be the reason why a significant decrease of spring maximum discharges can be noticed from 1971 to $1975-1977$, since then negative flood anomalies dominated in the most of the studied rivers. The analysis of trend magnitude performed by Reihan et al. (2007) showed that the greatest amount of change of meteorological parameters occurred during the period of 1961-2003. During this period the average winter temperature raised by $3{ }^{\circ} \mathrm{C}$ and precipitation increase was $43 \mathrm{~mm}$. These climate changes influenced a river discharge for the winter season. In such a way redistribution of spring runoff occurred, i.e. spring floods tended to start earlier because of the warmer winters and earlier snowmelt, and they became smaller.

In the last two decades the most spring flood maximum discharges were less than the mean value of the long term period.

Detected negative trends in spring flood data for the period of 1961-2010 confirmed the described tendencies. Decrease of the maximal discharge level and reduction of extreme yearly discharges recently in the Baltic rivers was estimated by other studies (e.g. Reihan et al. 2012) as well.

Already mentioned marine rivers the Minija and the Jura deviated from the other studied rivers the most. Big floods in these rivers were recorded in both periods before and after 1961; that may explain the absence of trends in the studied periods as well as in the whole period of 1922-2010. Catchments of these rivers are situated in Western Lithuania, this region is characterised by the highest amount of annual precipitation (735-810 $\mathrm{mm}$ ) and exactly precipitation comprises the greatest part of a river feeding (53\%) there. Moreover the catchments of the Minija and the Jura are small: the smaller a catchment, the shorter its response to changes of meteorological conditions is (Bagdziunaite-Litvinaite et al. 2011).

Long spring flood data series enable to use it for flood frequency analysis and make projection of floods of a certain probability. The analysis demonstrated that floods in the selected rivers may be most often represented by either GEV or LP3 distributions. These probability distribution models may be used for estimation of the design floods in the rivers of the studied area, and these models are among the most commonly applied in many countries (Abida, Ellouze 2008; Gubareva 2011) as well.

The observed variability of spring flood discharges in time is definitely climate driven, although the changing scale of urbanization plays significant role as well. Growing urban areas change infiltration capacities of water into the soil, consequently changing the runoff patterns within river catchments. It is difficult to get accurate and reliable data on land use in the studied territory, but other studies (like Theobald et al. 2009) show a significant 
impact of the land use changes on a maximum discharge formation. Other potential drivers of flood changes such as increased water use and deforestation (Preti et al. 2011) should not be forgotten as well. Combination of all these factors together makes estimation and prediction of flood events very complicated.

\section{Conclusions}

1. The performed analysis of big spring floods (probability of $\leq 10 \%$ ), calculated anomalies and trend analysis of maximum annual discharges showed no significant differences in spatial patterns among the different groups of rivers, but indicated obvious changes in their temporal behaviour, i.e. the decrease of spring floods in the studied rivers in the period of 1922-2010.

2. The performed probabilistic modelling of the flood discharge data and probability distribution fitting revealed that generalized extreme value and log-Pearson type III distributions represent the most valid model for the studied river data.

3. The detected changes of spring flood maximum discharges over time are definitely mainly climate driven.

\section{Acknowledgements}

A part of research described in this paper was supported by COST action ES0901 European procedures for flood frequency estimation and partly by Environmental protection and technology programme No 3.2.0802.11-0043 of European Regional Fund within the project EstKliima.

\section{References}

Abida, H.; Ellouze, M. 2008. Probability distribution of flood flows in Tunisia, Hydrology and Earth System Science 12: 703-714. http://dx.doi.org/10.5194/hess-12-703-2008

Apsite, E.; Bakute, A.; Elferts, D.; Kurpniece, L.; Pallo, I. 2011. Climate change impacts on river runoff in Latvia, Climate Research 48: 57-71. http://dx.doi.org/10.3354/cr01004

Arduino, G.; Reggiani, P.; Todini, E. 2005. Recent advances in flood forecasting and flood risk assessment, Hydrology and Earth System Sciences 9: 280-284.

http://dx.doi.org/10.5194/hess-9-280-2005

BACC Author Team 2008. Assessment of climate change for the Baltic Sea basin. Berlin Heidelberg: Springer. http://dx.doi.org/10.1007/978-3-540-72786-6

Bagdziunaite-Litvinaitiene, L.; Litvinaitis, A.; Saulys, V. 2011. Patterns of river runoff change considering the size of the basin, Journal of Environmental Engineering and Landscape Management 19(14): 326-334. http://dx.doi.org/10.3846/16486897.2011.634057

Barredo, J. I. 2009. Normalized flood losses in Europe: 19702006, Natural Hazards and Earth System Sciences 9: 97-104. http://dx.doi.org/10.5194/nhess-9-97-2009

Dankers, R.; Feyen, L. 2008. Climate change impact on flood hazard in Europe: an assessment based on high-resolution climate simulations, Journal of Geophysical Research 113, D19105. http://dx.doi.org/10.1029/2007JD009719

Dumbrauskas, A.; Bagdziunaite-Litvinaitiene, L.; Vyciene, G. 2008. Trend detection in hydrological series of main Lithuanian rivers, in The 7th International conference "Environmental Engineering”: Selected Papers, 22-23 May, 2008, Vilnius, Lithuania, 2: 508-514.

De Wrachien, D.; Mambretti, S.; Schultz, B. 2011. Flood management and risk assessment in flood-prone areas: measures and solutions, Irrigation and Drainage 60: 229-240. http://dx.doi.org/10.1002/ird.557

Gailiusis, B.; Jablonskis, J.; Kovalenkoviene, M. 2001. Lietuvos upes. Hidrografija ir nuotekis [The Lithuanian rivers. Hydrography and runoff]. Kaunas: LEI. $792 \mathrm{p}$.

Gilbert, R. O. 1987. Statistical methods for environmental pollution monitoring. New York: Van Nostrand Reinhold. 336 p.

Groisman, P. Y.; Knight, R. W.; Karl, T. R.; Easterling, D. R.; Sun, B.; Lawrimore, J. H. 2004. Contemporary changes of the hydrological cycle over the contiguous United States: trends derived from in situ observations, Journal of Hydrometeorology 5: 64-85. http://dx.doi.org/10.1175/15257541(2004)005<0064:CCOTHC>2.0.CO;2

Gubareva, T. S. 2011. Types of probability distributions in the evaluation of extreme floods, Water Resources 38(7): 962971. http://dx.doi.org/10.1134/S0097807811070074

Haylock, M. R.; Goodess, C. M. 2004. Interannual variability of extreme European winter rainfall and links with mean largescale circulation, International Journal of Climatology 24: 759-776. http://dx.doi.org/10.1002/joc.1033

Jaagus, J. 2006. Climate changes in Estonia during the second half of the 20th century in relation with changes in largescale atmospheric circulation, Theoretical and Applied Climatology 83(1-4): 77-88.

http://dx.doi.org/10.1007/s00704-005-0161-0

Kidson, R.; Richards, K. S. 2005. Flood frequency analysis: assumptions and alternatives, Progress in Physical Geography 29(3): 392-410. http://dx.doi.org/10.1191/0309133305pp454ra

Klavins, M.; Briede, A.; Rodinov, V. 2009. Long term changes in ice and discharge regime of rivers in the Baltic region in relation to climatic variability, Climatic Change 95: 485-498. http://dx.doi.org/10.1007/s10584-009-9567-5

Kriauciuniene, J.; Meilutyte-Barauskiene, D.; Reihan, A.; Koltsova, T.; Lizuma, L.; Sarauskiene, D. 2012. Variability in temperature, precipitation and river discharge in Baltic States, Boreal Environment Research 17: 150-162.

Latkovska, I.; Apsīte, E.; Elferts, D.; Kurpniece, L. 2012. Forecasted changes in the climate and the river runoff regime in Latvian river basins, Baltica 25(2): 143-152. http://dx.doi.org/10.5200/baltica.2012.25.14

Lehner, B.; Döll, P.; Alcamo, J.; Henrichs, T.; Kaspar, F. 2006. Estimating the impact of global change on flood and drought risk in Europe: a continental, integrated analysis, Climatic Change 75: 273-299. http://dx.doi.org/10.1007/s10584-006-6338-4

Mitosek, H. T.; Strupczewski, W. G.; Singh, V. P. 2006. Three procedures for selection of annual flood peak distribution, Journal of Hydrology 323(1-4): 57-73. http://dx.doi.org/10.1016/j.jhydrol.2005.08.016

Preti, F.; Forzieri, G.; Chirico, G. B. 2011. Forest cover influence on regional flood frequency assessment in Mediterranean 
catchments, Hydrology and Earth System Sciences 15: 30773090. http://dx.doi.org/10.5194/hess-15-3077-2011

Reihan, A.; Koltsova, T.; Kriauciuniene, J.; Lizuma, L.; MeilutyteBarauskiene, D. 2007. Changes in water discharges of the Baltic States rivers in the 20th century and its relation to climate change, Nordic Hydrology 38(4-5): 401-412.

http://dx.doi.org/10.2166/nh.2007.020

Reihan, A.; Kriauciuniene, J.; Meilutyte-Barauskiene, D.; Kolcova, T. 2012. Temporal variation of spring flood in rivers of the Baltic States, Hydrology Research 43(4): 301-314. http://dx.doi.org/10.2166/nh.2012.141

RPV SSSR (Surface water resources of USSR). 1972. Protasjeva, M. S.; Eipre, T. F. (Eds.). Leningrad: Gidrometeoizdat, 106-119 (in Russian).
Sarauskiene, D.; Kriauciuniene, J. 2011. Flood frequency analysis of Lithuanian rivers, in Environmental Engineering: 8th International Conference, 19-20 May 2011, Vilnius, Lithuania, 2: 666-671.

Theobald, D. M.; Goetz, S. J.; Norman, J. B.; Jantz, P. 2009. Watersheds at risk to increased impervious surface cover in the conterminous United States, Journal of Hydrologic Engineering 14(4): 362-368. http://dx.doi.org/10.1061/(ASCE)1084-0699(2009)14:4(362)

Villarini, G.; Smith, J. A.; Serinaldi, F.; Ntelekos, A. A. 2011. Analyses of seasonal and annual maximum daily discharge records for central Europe, Journal of Hydrology 399(3-4): 299-312.

http://dx.doi.org/10.1016/j.jhydrol.2011.01.007

Diana SARAUSKIENE. Dr, Senior Research Associate, Laboratory of Hydrology, Lithuanian Energy Institute, Lithuania. Bachelor of Science (biology), Vytautas Magnus University, 1994; Master of Science (environmental management), Vytautas Magnus University, 1996; Doctor of Physical Sciences (geography), Lithuanian Energy Institute, 2002. Publications: author of 13 scientific publications. Research interests: climate impact on river runoff, floods and thermal regime, research of thermal regime of water bodies, ice formation.

Jurate KRIAUCIUNIENE. Dr, Head of Laboratory of Hydrology, Lithuanian Energy Institute. Doctor of Natural sciences (geography) of Lithuanian Energy Institute, 1998. Publications: over 60 scientific publications. Research interests: modelling of hydrodynamics, waves, sediment and advection-dispersion processes; assessment of anthropogenic and natural impact on the hydrological regime of water bodies; climate change and water recourses.

Alvina REIHAN. Dr, Hydrologist, Assoc. Prof. of Department of Environmental Engineering, Tallinn University of Technology. Doctoral degree in Civil Engineering. Publications: over 20 scientific publications. Research interests: climate change impact on surface water resources and water quality, river runoff modelling, water balance, water resources estimation and management and scenarios for water management.

Maris KLAVINS. Dr hab. chem., Professor at the University of Latvia, Faculty of Geography and Earth Sciences, Department of Environmental Sciences. He obtained his scientific degree in chemistry of biologically active compounds at the Moscow State University in 1986 but a habilitation degree at the University of Latvia in 1994. He is a member of the Academy of Sciences of Latvia. Research interests are related to studies of natural organic matter, wetlands and bogs, surface water hydrology and environmental pollution problems. 